\title{
Historical accumulation of potentially toxic trace elements resulting from mining activities in estuarine salt marshes sediments of the Asturias coastline (northern Spain)
}

\author{
Efrén Garcia-Ordiales ${ }^{1}$ (iD $\cdot$ Pablo Cienfuegos ${ }^{1} \cdot$ Nieves Roqueñí $^{1} \cdot$ Stefano Covelli $^{2,3}$. \\ German Flor-Blanco $^{4}$. Giorgio Fontolan ${ }^{2,3}$. Jorge Loredo ${ }^{1}$
}

Received: 30 April 2017 / Accepted: 9 October 2017 /Published online: 20 October 2017

(C) Springer-Verlag GmbH Germany 2017

\begin{abstract}
The extensive extraction activity of mercury ores in Asturias (northwest Spain), also rich in As and Sb, has impacted the Nalón river estuary. The objective of this research was to assess the historical evolution of As-Hg-Sb accumulation in the salt marsh sediments of this area. For this purpose, sediment cores were collected from two different salt marshes (eastern and western river banks) in the estuarine environment to evaluate the degree of anthropogenic enrichment and the geochronology of As-Hg-Sb accumulation. Core subsampling was performed by cutting 2 -cm-thick slices of sediments. The subsamples were then analysed for several physical and chemical parameters. Sedimentation rate was assessed by measuring short-lived radionuclides (excess ${ }^{210} \mathrm{~Pb}$ and ${ }^{137} \mathrm{Cs}$ ). Premining levels of As-Hg-Sb were observed at core depths below $50 \mathrm{~cm}$. In the less extended salt marsh (eastern river bank), maximum As-Hg-Sb concentrations of 87.48, 3.66, and $5.75 \mu \mathrm{g} \cdot \mathrm{g}^{-1}$, respectively, were found at the core top as a consequence of long-term mining activity in the area. The vertical distribution of $\mathrm{As}-\mathrm{Hg}-\mathrm{Sb}$ was influenced by the single-point contamination sources, whereas grain-size
\end{abstract}

Responsible editor: Severine Le Faucheur

Efrén Garcia-Ordiales

garciaefren@uniovi.es

1 ISYMA Research Group, Mining, Energy and Materials Engineering School, University of Oviedo, Oviedo, Spain

2 Department of Mathematics and Geosciences, University of Trieste, Trieste, Italy

3 Co.N.I.S.Ma. Consorzio Nazionale Interuniversitario per le Scienze del Mare, Piazzale Flaminio 9, 00196 Rome, Italy

4 GeoQUO Research Group, Department of Geology, University of Oviedo, Oviedo, Spain variability and diagenetic remobilisation did not seem affected. Geochronological measurements showed that the depositional fluxes of As-Hg-Sb were influenced by anthropogenic input after 1900, when mining activity in the area was most intense. Hg mining ceased in 1969; however, the corresponding core profiles did not show a drastic decreasing trend in element fluxes, implying that the river drainage basin retains some "memory" of contamination which affects riverine sediments. A preliminary gross estimation of total As- $\mathrm{Hg}-\mathrm{Sb}$ "trapped" in the Nalón river salt marsh sediments amounted to approximately $18.7,1.0$, and $0.7 \mathrm{t}$, respectively. These morphological structures suffer erosive processes, thus representing a potential source of these elements associated with sediments; consequently, management conservation and monitoring of salt marshes should be taken into consideration from this environmental point of view.

Keywords Geochronology · Salt marshes · Sediments . Mining $\cdot$ Mercury $\cdot$ Arsenic

\section{Introduction}

Estuaries are coastal environments with high ecological value where river and marine elements coexist. The dynamics between the fresh and marine environments produce large deposition areas of materials resulting from the contributions of the river basin and of the coastal zone during flood tides (Verney et al. 2011; Cuvilliez et al. 2015). Salt marshes are depositional morphological features within the estuarine zone where sediments accumulate (Duarte et al. 2017). They often show a 'memory effect', meaning that they are able to chronologically record significant events in the area (Roner et al. 2016). This sedimentary record may register hydrological phenomena as well as contamination events occurring in the river 
drainage basin (Idaszkin et al. 2017). A large number of contaminants derived from human activities have been continuously introduced into river courses and transported for long distances downstream, reaching the coastal zone. Transported inorganic contaminants are mainly in the solid phase rather than in dissolved form and they are deposited or captured by salt marshes which act as a sink. The investigation of the concentration profiles in the sedimentary sequence of salt marshes allows for the reconstruction of the historical human impact on the river basin and the estuarine environment (Birch, 2017).

Among human activities, mining is recognised as a notable source of contaminants to freshwater areas. In mining areas, tailings and wastes still contain elevated levels of contaminants due to inefficient mining and smelting operations, thus behaving as important secondary sources of contaminants in the surrounding environment. Mobilisation of contaminants from these tailings and waste disposal sites due to complex biological, geochemical, and physical processes, including erosion, hydrolysis, and oxidation of sulphur minerals (Audry et al. 2005), as well as the weathering of secondary phases (Hammarstrom et al. 2005) represents important environmental threats. Once contaminants have been introduced into hydrological systems, they can be dispersed over hundreds of kilometres in solid or dissolved forms (Chen et al. 2007; Covelli et al. 2012; García-Ordiales et al. 2014), extending their impact to areas far away from the original source. After the cessation of mining activities, waste material can continue to be a source of long-term contamination, as weathering and/or hydrological phenomena can remove contaminants from the mining site and transport them downstream.

The Asturias region (northern Spain) has historically been one of the most important mining regions of the country. In its central part, approximately $60 \%$ of the territory is drained by the Nalón river basin, which forms the largest hydrogeological system in the north of Spain. The largest coal deposits in Spain lie within the river drainage basin, in the so-called Asturian Central Coal Basin, and have been exploited for more than 200 years. Such mining activity continues in this area. In the same drainage basin, together with the coal mining, other metallic and non-metallic deposits are or have been exploited, among which, cinnabar deposits stand out. The Nalón river basin hosts the important $\mathrm{Hg}$ deposits of La Peña-Terronal and Soterraña as well as many other minor deposits, making this area the second largest producer of $\mathrm{Hg}$ in Spain and the fourth largest in Europe, after the mining areas of Almadén (Spain), Idrija (Slovenia), and Monte Amiata (Italy). Weathering of these $\mathrm{Hg}$ deposits, where elements such as $\mathrm{As}$ and $\mathrm{Sb}$ appear in their mineral paragenesis, as well as different lithological materials and other polymetallic deposits, has led to a high regional background level of these potentially toxic elements (IGME 2012). Together with the naturally enriched presence of these elements, several studies on soils, water, and sediments in the areas near the mines, reviewed by Ordóñez et al. (2013), have shown the existence of important flows of $\mathrm{As}-\mathrm{Hg}$-Sb from the mining areas to the river courses and the estuarine environment. In order to investigate the legacy left by mining activity in the drainage basin and the contribution of natural weathering to the geochemical levels of As- $\mathrm{Hg}-\mathrm{Sb}$ in the estuary, sediment cores were collected from two natural salt marshes in the estuary, and their concentration profiles were studied. In addition, the geochronology of the sedimentary sequence has allowed the establishment, on the one hand, of the pre-mining activity value of each element and, on the other hand, the estimation of the current amount of $\mathrm{Hg}$, As and $\mathrm{Sb}$ stored in these morphological features.

\section{Materials and methods}

\section{Study area}

The Nalón river estuary is located along the northern coastline of Spain, in the Asturias region (Fig. 1). The largest hydrosystem of the region, which covers an area of $4777 \mathrm{~km}^{2}$, drains into this estuarine area. At the basin level, the different rivers flow on Paleozoic materials, covering in their water course materials from the Cambrian to the Upper Carboniferous periods. The western sector of the drainage basin is characterised by the presence of low-grade metamorphic siliciclastic rocks interbedded with calcareous series of grey limestones and dolomites; in the eastern part, the calcareous and siliciclastic series predominate (Julivert et al. 1972). Several urban settlements along with various agricultural and mining-industrial activities are located in the area. Among the mining-industrial activities, which have been active in the upper-middle sector of the drainage basin since the end of the eighteenth century, the most important is related to the remarkable deposits of coal, mercury, gold, and iron as well as other polymetallic ores, such as copper, lead, and zinc. The most notable $\mathrm{Hg}$ deposits are La Peña-Terronal in Mieres and La Soterraña in Pola de Lena. The first one is the most important; it is located in the northwest margin of the Central Carboniferous Basin of Asturias and belongs to the geological area of the unit named La Justa-Aramil. Mineralisation in the carboniferous levels, constituted by conglomerates with siliceous clasts, relates the ore to the La Peña fault (Luque 1985). In the La Soterraña Hg mining area, the mineralisation is associated with three fine-grained limestone levels that are rich in organic matter, embedded in the carbonate levels of the Lena Group. The main ore mineral of these deposits is cinnabar in association with native $\mathrm{Hg}$, stibnite $\left[\mathrm{Sb}_{2} \mathrm{~S}_{3}\right]$, and important amounts of As-bearing minerals such as realgar and pararealgar $\left[\mathrm{As}_{4} \mathrm{~S}_{4}\right]$, orpiment $\left[\mathrm{As}_{2} \mathrm{~S}_{3}\right]$, and arsenic-rich pyrite (Ordoñez et al. 2013). 


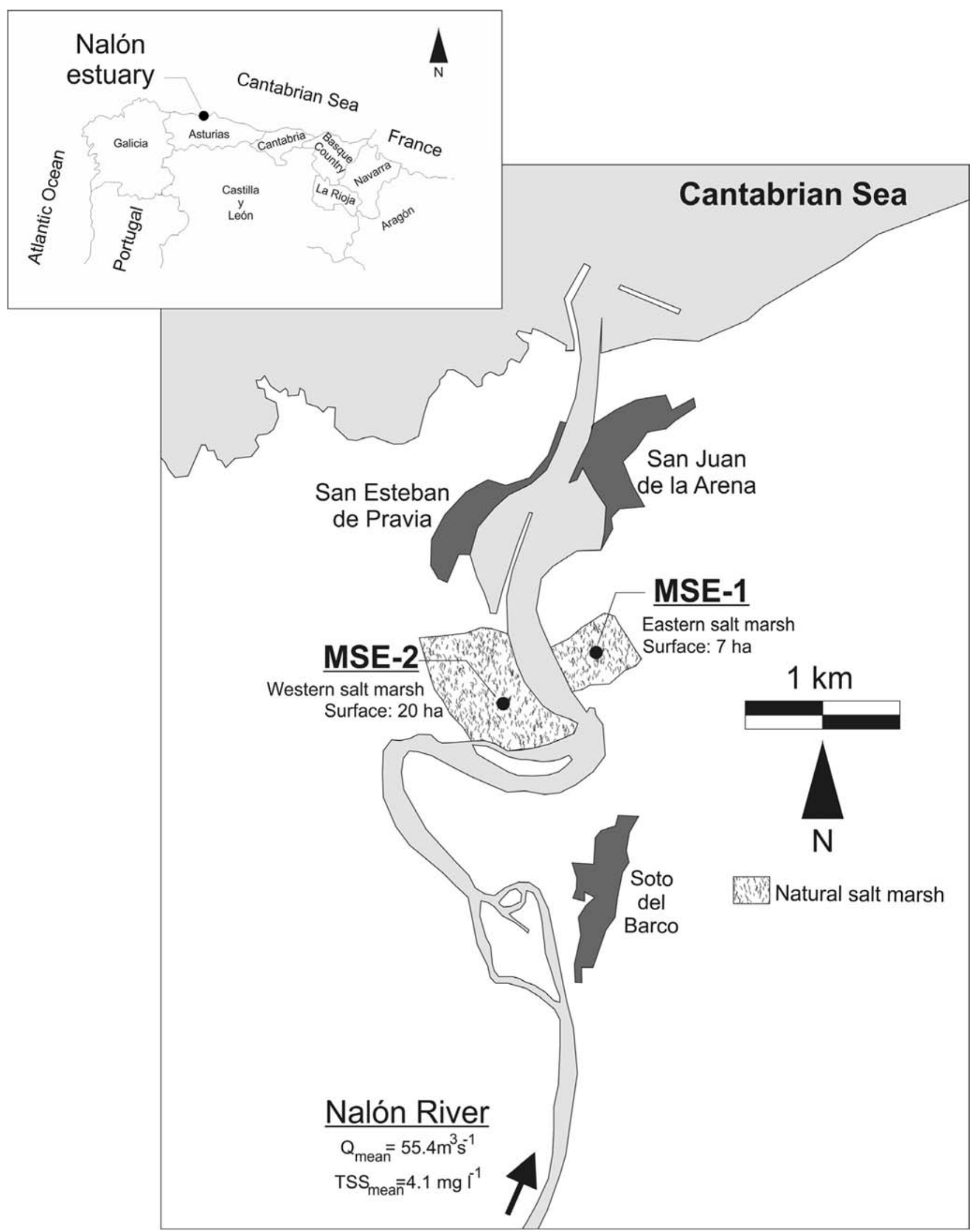

Fig. 1 The Nalón river estuary with the essential features and the salt marsh areas from where the sediment cores were collected 
The estuarine area of the Nalón River is characterised by a main channel which is 6-km long and above 2-m deep, which has been modified in the mouth by two jetties since 1946, changing the morphology and the sedimentation of the outer part of the estuary (Flor-Blanco et al. 2015). The lowest section of the estuary runs perpendicular to the coastline, with some meanders in the upper section. The tidal regime of the estuary is meso-tidal, with annual tidal ranges between 1.0 to $4.2 \mathrm{~m}$, being in general the tides over $2 \mathrm{~m}$ during more than $70 \%$ of the year (Flor et al. 1998). Based on morphodynamics and according to the land elevation and tidal influence, two different units can be distinguished, as observed in similar environments along the British (Allen and Rae 1988; Allen 1989), French (Larsonneur 1975), and Cantabrian coastlines (Mantecón and Uceda 1992; Cearreta et al. 1992). The uppermost section of the estuary, with the highest land elevations, features a strong fluvial domain that inhibits the growth of halophilic species. The surrounding soils are flooded by freshwaters only during high river stages. The lowest sector of the estuary is tide-dominated and the high tides regularly flood the salt marsh areas, allowing the development of halophyte vegetation. The two natural marshes investigated in this study (Fig. 1), which cover a total area of 27 ha, are located in this sector. Both salt marshes are characterised by a muddy substratum as a consequence of its development in sedimentary deposition zones, and they are colonised by halophilic or subhalophilic species such as Scirpus maritimus var. compactus, Phragmites australis, and Juncus maritimus.

\section{Coring and sample handling}

Four sediment cores (diameter, $8 \mathrm{~cm}$; length, $60 \mathrm{~cm}$ ) were recovered from the central zone of the marshes in 2017 (Fig. 1). At each sampling point, two twin cores were taken by means of an AMS sludge and sediment sampling kit equipped with a polyvinyl chloride (PVC) tube for uncharged sample recovery. Between the two consecutive samplings, adhered residues were removed from the equipment with a $10 \% \mathrm{HNO}_{3}$ solution and rinsed several times with Milli-Q water to avoid cross-contamination. The sediment cores were transported to the laboratory, where they were manually subsampled as 2-cm discs (for a total number of 30 samples per core). Subsamples were weighed and air-dried to a constant weight to calculate bulk density and porosity; they were manually ground and root residues removed at the same time. One of the two cores from each salt marsh was used exclusively for chronological dating analyses, while the twin core was used for physical and geochemical analyses. Samples used for chronological dating were individually stored in plastic bags, while those used for physical and geochemical analyses were preliminarily sieved to $2 \mathrm{~mm}$ to discard the gravel fraction. Subsamples for geochemical analyses were homogenised and split into aliquots. The bulk density was determined on untreated aliquots.

\section{Radiometric analyses of ${ }^{137} \mathrm{Cs}$ and ${ }^{210} \mathrm{~Pb}$}

Radiometric analyses of ${ }^{137} \mathrm{Cs}$ and ${ }^{210} \mathrm{~Pb}$, which are wellestablished techniques to obtain sediment accumulation rates over the past 50 to 150 years in sediments of coastal environments (Mahu et al. 2016; Andersen 2017), were performed at the Instytut Nauk Geologicznych (Poland). The activities of ${ }^{137} \mathrm{Cs}$ and ${ }^{210} \mathrm{~Pb}$ in the sedimentary sequences were measured by y spectrometry using a BE5030 instrument (CANBERRA) and GENIE 2000 software to date the vertical sediment profiles. The ${ }^{210} \mathrm{~Pb}_{\text {excess }}$ activity was determined by subtracting ${ }^{210} \mathrm{~Pb}_{\text {supp }}$ (as average of ${ }^{214} \mathrm{~Pb}$ and ${ }^{214} \mathrm{Bi}$ activities) from total ${ }^{210} \mathrm{~Pb}$ for each depth interval. Detector efficiencies were calibrated using several sources and confirmed using IAEA standard material (IAEA-384) with results falling within $1 \sigma$ of the certified value and the variation coefficient between 3.5 and $4.2 \%$. The uncertainty of the chronology and the sedimentary accumulation rate (Fig. 2) was calculated in the lab using the Monte Carlo simulation method (Sanchez-Cabeza et al. 2014).

The first high levels of ${ }^{137} \mathrm{Cs}$ appeared in the atmosphere in the early 1950s (1954), but the period of greatest deposition and therefore of greatest activity occurred in the early $1960 \mathrm{~s}$ (1963) as consequence of atmospheric nuclear tests (Ritchie and McHenry 1990). Based on this evidence, the date 1963 is assigned to the sedimentary specimen with the highest activity of ${ }^{137} \mathrm{Cs}$, which is commonly accepted as the main chronological marker for this radioisotope. Note that the ${ }^{137} \mathrm{Cs}$ peak related to Chernobyl accident (1986) was not considered as a potential marker for the highest activity of ${ }^{137} \mathrm{Cs}$ as low deposition occurred in the north of Spain after the disaster (De Cort 1998; Cearreta and Leorri 2009). For the ${ }^{210} \mathrm{~Pb}$ dating, the constant flow model (Appleby and Oldfield 1983) was used to relate sediment age and depth by assuming constant depositional flux of ${ }^{210} \mathrm{~Pb}$ to the salt marsh surface. Peak ${ }^{137} \mathrm{Cs}$ at 1963 provided independent corroboration of the ${ }^{210} \mathrm{~Pb}$ accumulation history.

\section{Physical and geochemical analyses of sediments}

Sediment grain size was determined by using Fritsch ANALYSETTE MicroTec Plus 22 laser particle sizers. Previously, the selected aliquots were oxidised via a solution of $3 \%(v / v) \mathrm{H}_{2} \mathrm{O}_{2}$ to remove most of the organic matter. Each sample was analysed in triplicate; the instrument was checked against the Fristch F500 and F70 as reference materials. Estimation of the organic matter and carbonate content was performed by the loss on ignition (LOI) method burning the samples at $550{ }^{\circ} \mathrm{C}$ for $4 \mathrm{~h}$, according to the recommendations of Heiri et al. (2001) for samples with high organic matter contents. For the general semi- 
Fig. 2 Uncertainties of the ${ }^{210} \mathrm{~Pb}$ chronology and the mass sedimentation rate calculated by means of the Monte Carlo simulation method

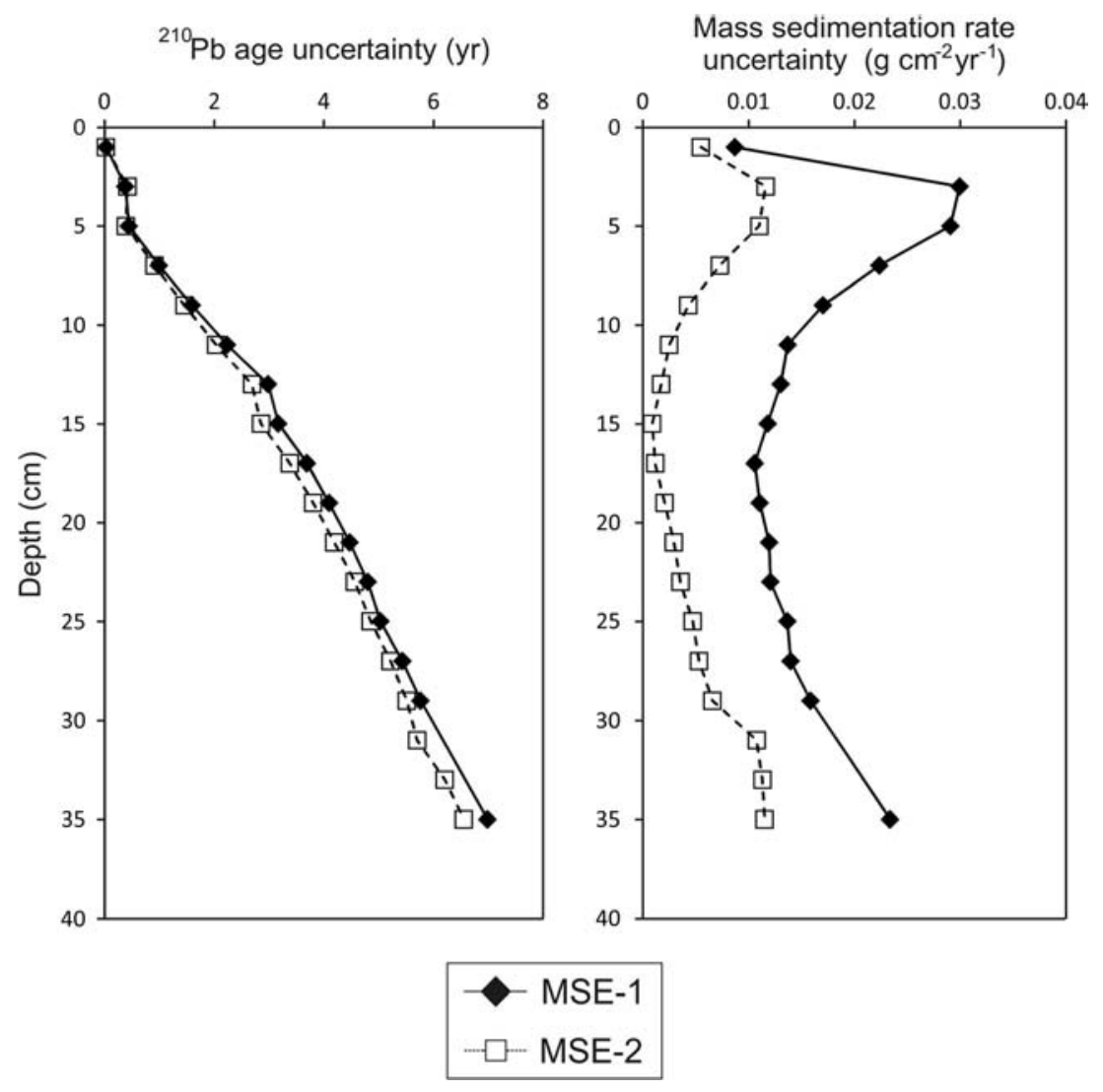

quantitative mineralogical analysis, approximately $2 \mathrm{~g}$ of sample was ground in an agate mortar to a size smaller than $25 \mu \mathrm{m}$ and analysed via X-ray diffraction (XRD). To determine phyllosilicates in detail, $20 \mathrm{~g}$ of sample was dispersed by agitation in an aqueous solution, and the fraction below $2 \mu \mathrm{m}$ was recovered via sedimentation techniques and analysed according to Moore and Reynolds (1989). Samples were measured using a Bruker D8 Discover Xray diffractometer according to internal protocols of the University of Oviedo. For the elemental analysis of the samples, the aliquots were ground using an agate mortar to a size below $63 \mu \mathrm{m}$. For the measurement of some major (Al, Fe, Mn, and Si) and trace elements (As and Sb), samples were pressed into pellets using added lithium borate as a binder. The resulting pellets were analysed via portable X-ray fluorescence spectrometry (XRF) using a Thermo Niton XL3t Goldd + spectrophotometer. Samples were analysed in batches, and quality control was evaluated through duplicate analyses of certified reference materials NIST 2710 and STSD-1. Limits of detection (LOD) and quantification (LOQ) of the XRF are present in Table 1. Mercury was analysed by direct pyrolysis using a LECO AMA 254 advanced mercury analyser; for each sample, three replicates were made and quality control was performed using reference materials PACS-2 and Sandy Loam 2 (recovery 96 and $98 \%$, respectively).

\section{Results and discussion}

\section{Lithology, mineralogy, and major elements of sediments}

The mineralogical composition of the sediments from the Nalón river estuary salt marshes is mainly quartz, which is predominant in the coarse fractions, and kaolinite-smectite, illite, albite, and vermiculite in the finer fractions. Sediments are generally dominated by fine grain-size particles typical of low-energy environments; the sandy fraction was the least abundant (approx. 8.0\%).

The analytical results from the two cores are visualised in Fig. 3. The significant presence of silt ( $83.1 \%)$ and clay (8.9\%), according to the discriminant function proposed by Sahu (1964) for the characterisation of depositional settling of the

Table 1 Limits of detection (LOD) and limits of quantification (LOQ) of selected major elements and trace elements determined with XRF in a quartz sample $(\mathrm{mg} / \mathrm{kg})$ with and internal calibration curve (density of points 12). The selected time for each analysis was $45 \mathrm{~min}$ according to laboratory tests to improve the LOD and LOQ of the equipment

\begin{tabular}{llllrll}
\hline & $\mathrm{Al}_{2} \mathrm{O}_{3}$ & $\mathrm{Fe}_{2} \mathrm{O}_{3}$ & $\mathrm{MnO}$ & $\mathrm{SiO}_{2}$ & \multicolumn{1}{c}{$\mathrm{As}$} & $\mathrm{Sb}$ \\
\hline LOD & 0.41 & 0.02 & 0.003 & 4.61 & 0.55 & 0.37 \\
LOQ & 2.83 & 0.09 & 0.010 & 21.39 & 3.01 & 1.59 \\
\hline
\end{tabular}



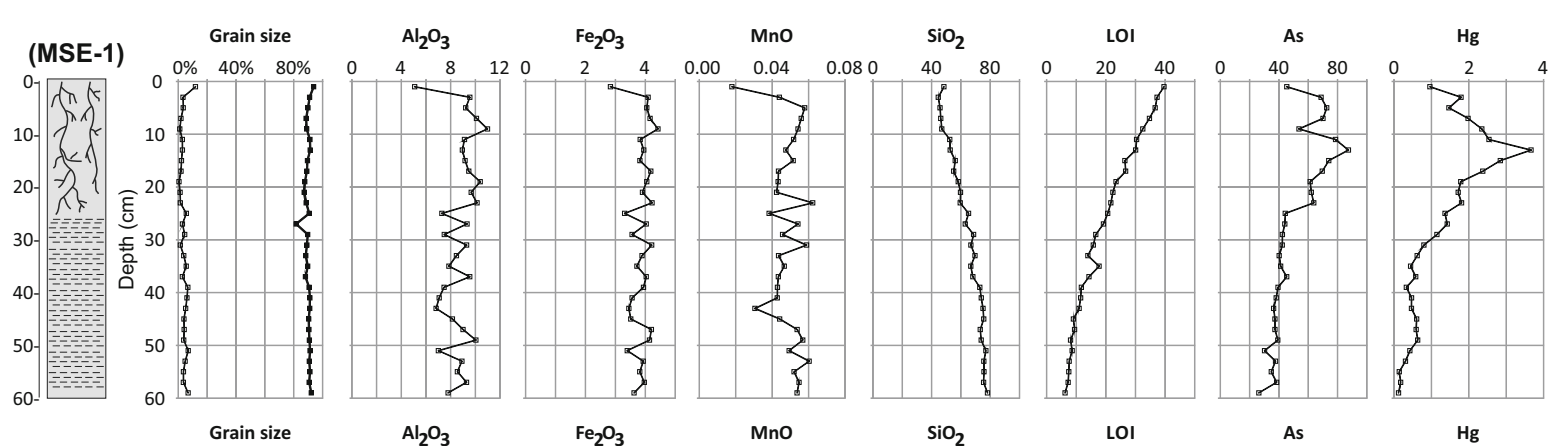

$\mathrm{Sb}$
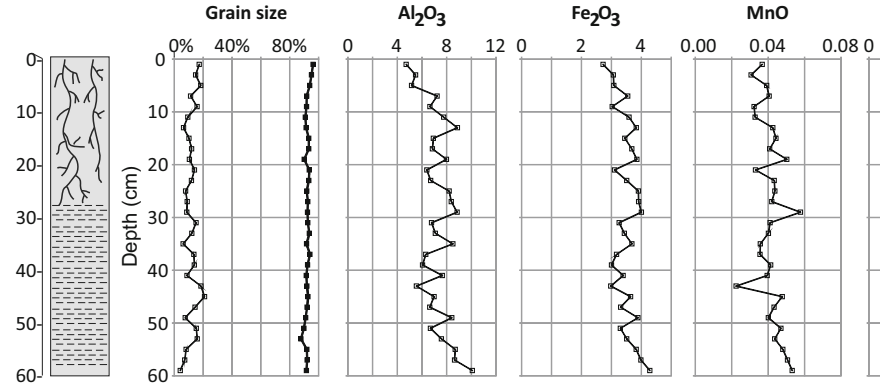

$\mathrm{SiO}_{2}$

LOI

As
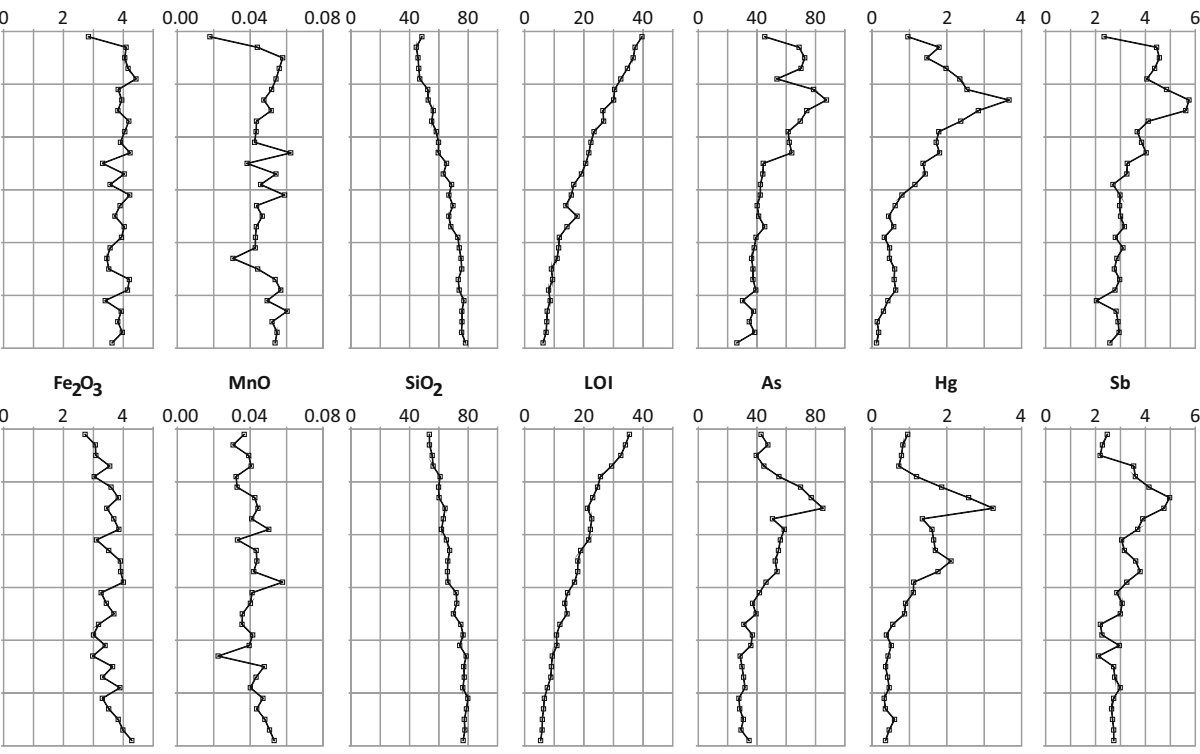

Sb

(MSE-2)

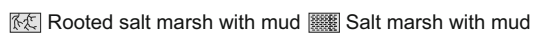

Fig. 3 Vertical profiles of grain size (\% sand content in open squares, \% sand + silt content in black squares), $\mathrm{Al}_{2} \mathrm{O}_{3}, \mathrm{Fe}_{2} \mathrm{O}_{3}, \mathrm{MnO}, \mathrm{SiO}_{2}$ and $\mathrm{LOI}$ (reported as \% dw) and of As, $\mathrm{Hg}$ and Sb (reported as $\mu \mathrm{g} \mathrm{g}^{-1}$ ) in core MSE-1 and MSE-2

sediments, supports the fluvial provenance of the sediments, which were deposited in a low-energy environment on the salt marshes (Garcia-Ordiales et al. 2015). However, there are some differences in the salt marsh granulometry sequence along the riversides. The sediment core related to the western salt marsh (MSE-2) shows a greater percentage of sands than does the eastern salt marsh core (MSE-1), corresponding to the inner and the outer part of a meander zone of the river, respectively.

The chemical concentrations in the sediments reported as oxides are clearly dominated by $\mathrm{SiO}_{2}(66.3 \%)$ and $\mathrm{Al}_{2} \mathrm{O}_{3}$ $(8 \%)$, in addition to the significant presence of light amounts of $\mathrm{Fe}_{2} \mathrm{O}_{3}(3.7 \%)$, as expected based on the mineralogical analysis. Organic matter dominated the volatile contents since the carbonate fraction was practically negligible. Detected concentrations of $\mathrm{MnO}$ were consistently less than $1 \%$. Trends of $\mathrm{SiO}_{2}$ and LOI profiles in both cores are opposite: the LOI concentrations increase upwards to the surface whereas $\mathrm{SiO}_{2}$ concentrations decrease as a consequence of the decrease in the mineral matter present in the samples. Profile distributions of the main oxides are very homogeneous in both cores (the mean values are similar to the median values). The ratio of $\mathrm{SiO}_{2}$ to $\mathrm{Al}_{2} \mathrm{O}_{3}$, as a characterisation of the textural maturity of sediments, ranges between 4 to 10 , indicating a similar textural maturation. This result along with the predominance of medium grain size indicates short-term sedimentary cycling as a consequence of the extension of the drainage basin which has not allowed the sediments to spend long time in the sedimentary mill.

As the elemental concentrations in the core profiles might have been altered by diagenetic remobilisation due to redox changes, we further investigated the concentrations of $\mathrm{Al}, \mathrm{Fe}$, and Mn. These elements were selected based on other studies performed in coastal salt marsh areas such as those by Conaway et al. (2004) and Pasternack and Brown (2006). In these studies, the correlations among these three metals were explored as evidence of post-depositional mobility of redoxsensitive elements. If the redox active metals, $\mathrm{Fe}_{2} \mathrm{O}_{3}$ and $\mathrm{MnO}$, co-vary independently from aluminium, then diagenetic changes due to redox conditions may have occurred, potentially affecting the $\mathrm{As}-\mathrm{Hg}-\mathrm{Sb}$ concentrations.

The sediments show a significant linear relationship $\left(r^{2}=0.938 ; p<0.001\right)$ between $\mathrm{Al}_{2} \mathrm{O}_{3}$ and $\mathrm{Fe}_{2} \mathrm{O}_{3}$, between $\mathrm{Al}_{2} \mathrm{O}_{3}$ and $\mathrm{MnO}\left(r^{2}=0.704 ; p<0.001\right)$, and between $\mathrm{Fe}_{2} \mathrm{O}_{3}$ and $\mathrm{MnO}\left(r^{2}=0.741, p<0.001\right)$, indicating that all are very closely related. Although the range of $\mathrm{Al}_{2} \mathrm{O}_{3}$ and $\mathrm{Fe}_{2} \mathrm{O}_{3}$ concentrations in the cores is wide $(4.7-11.0 \%$ and $2.7-4.4 \%$, respectively), the linear relationship between both the elements and the fine-grain fraction $\left(r^{2}>0.780 ; p<0.001\right)$ indicates that this is due to changes in the abundance of aluminosilicate minerals in the core sediments. The lower correlation of $\mathrm{MnO}$ with the fine fraction $\left(r^{2}=0.551 ; p<0.001\right)$ indicates that its variability is not directly related to the aluminosilicate minerals. Consequently, the different behaviour of $\mathrm{MnO}$ in sediments in comparison to that of $\mathrm{Al}_{2} \mathrm{O}_{3}$ and $\mathrm{Fe}_{2} \mathrm{O}_{3}$ can lead to misinterpretation of potential diagenetic remobilisation. Therefore, concentration profiles of $\mathrm{MnO}$ were discarded for investigation of this aspect. As reported in Fig. 2, both vertical profiles of $\mathrm{Al}_{2} \mathrm{O}_{3}$ and $\mathrm{Fe}_{2} \mathrm{O}_{3}$ in the cores are similar, without apparent significant variations in their trends. This null variation suggests that $\mathrm{Fe}_{2} \mathrm{O}_{3}$ has undergone relatively little diagenetic remobilisation; consequently, the same applies to the redox-sensitive elements As-Hg-Sb as explained later. 


\section{Radionuclide profiles}

The activities of ${ }^{137} \mathrm{Cs}$ and the excess of ${ }^{210} \mathrm{~Pb}$ (Fig. 4) along the profiles are very similar in both salt marsh cores. In core MSE-1, the maximum peak of ${ }^{137} \mathrm{Cs}$, which is assumed to be a consequence of atmospheric nuclear tests in the early 1960s (1963), is observed at a depth of $15 \mathrm{~cm}$. Although ${ }^{137} \mathrm{Cs}$ is more mobile in the marine environment than ${ }^{210} \mathrm{~Pb}$, it is commonly used as an independent method to confirm ${ }^{210} \mathrm{~Pb}$-based estimates of sediment accumulation rates. In the salt marsh, surface-mixed layers and significant down-core fluctuations, according to porosity and grain size, were not noticeable. Thus, the sediment accumulation rate for MSE-1 (Table 2) based on ${ }^{210} \mathrm{~Pb}$ and ${ }^{137} \mathrm{Cs}$ was calculated using the upper region between 0 and $15 \mathrm{~cm}\left({ }^{137} \mathrm{Cs}\right.$ peak), resulting in similar values of 0.29 and $0.28 \mathrm{~cm} \mathrm{year}^{-1}$, respectively. For the MSE2 core, the region selected was between 0 and $19 \mathrm{~cm}\left({ }^{137} \mathrm{Cs}\right.$ peak), which also results in closely similar mean values of $0.37 \mathrm{~cm}$ year ${ }^{-1}$ for ${ }^{210} \mathrm{~Pb}$ and $0.35 \mathrm{~cm}$ year ${ }^{-1}$ for ${ }^{137} \mathrm{Cs}$. Based on the similarity between the sediment accumulation rates calculated by means of ${ }^{210} \mathrm{~Pb}$ and ${ }^{137} \mathrm{Cs}$ for each core, the constant flow model (Appleby and Oldfield 1983) applied for
${ }^{210} \mathrm{~Pb}$ was correct, and the dating of ${ }^{210} \mathrm{~Pb}$ is coincident with the dating obtained via ${ }^{137} \mathrm{Cs}$. In addition, the presence of two clear steps is remarkable (two in the MSE-1 core and one in the MSE-2) in the excess ${ }^{210} \mathrm{~Pb}$ profiles. These evidences were considered a consequence of substantial changes of the sedimentation environment in these sections rather than a potential existence of incomplete sedimentary records. The proof is the agreement between the ${ }^{137} \mathrm{Cs}$ and ${ }^{210} \mathrm{~Pb}$ dating immediately before and after these steps, which would have not occurred in the case of an incomplete sedimentary record.

The two salt marsh cores show differences in their accumulation rates based on ${ }^{210} \mathrm{~Pb}$ and ${ }^{137} \mathrm{Cs}$. Both sampling points are located in depositional areas on opposing riverbanks of the estuarine channel. The difference between the accumulation rates may be due to the different river hydrodynamics on opposite sides of the meander: the western salt marsh built up over an active point bar, and the eastern marsh developed along a small embayment infilled along a rectified tract of the river immediately downstream of a small residual relief, which formed a pond-like sediment trap. As a result of the different morphodynamic contexts, the highest sedimentation rate is observed in the western salt marsh core (MSE-2).

\section{Core MSE-1}

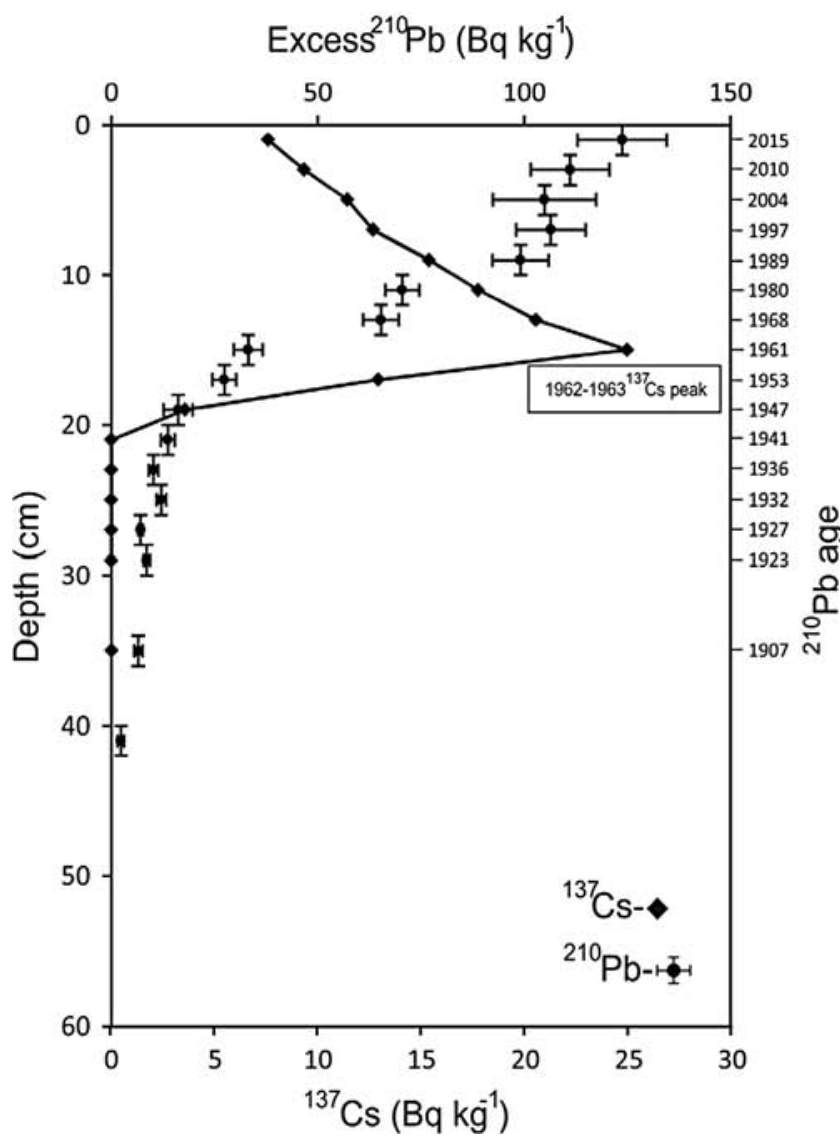

\section{Core MSE-2}
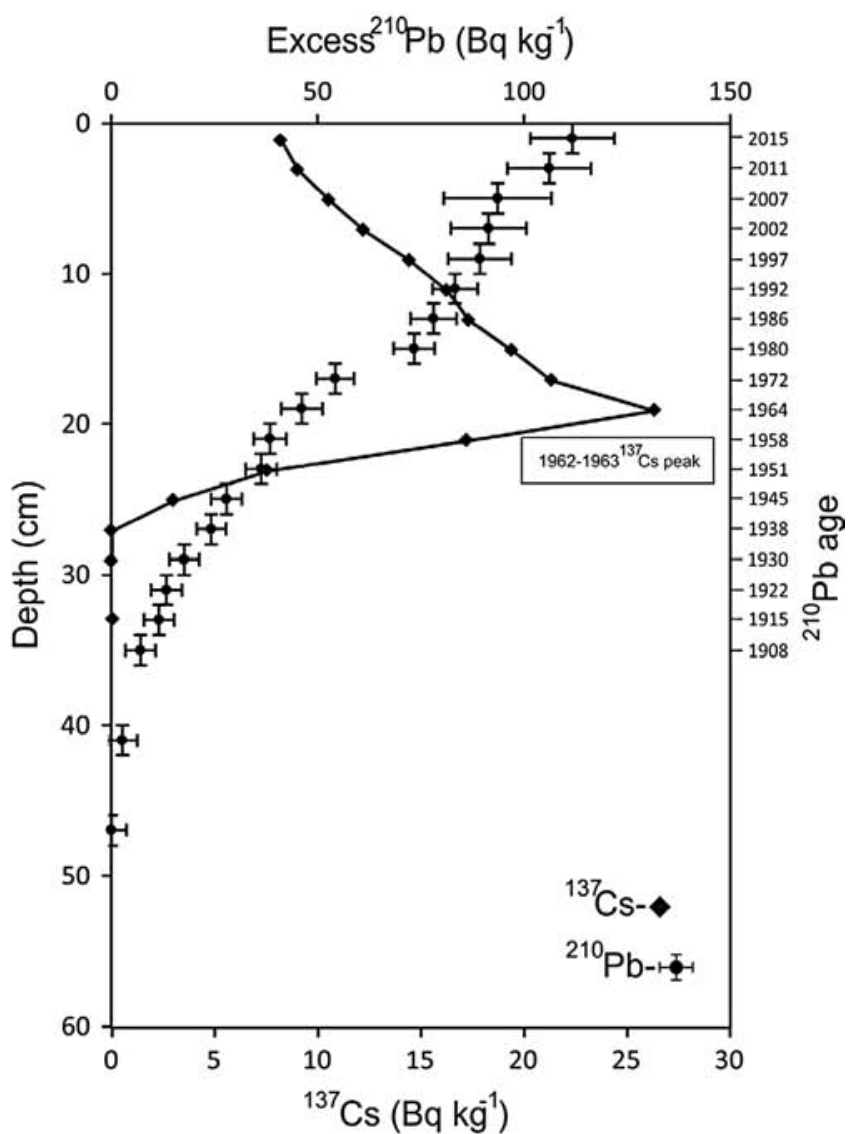

Fig. 4 Activity depth profiles of ${ }^{137} \mathrm{Cs}$ and excess ${ }^{210} \mathrm{~Pb}$ in the sediment cores collected at MSE-1 and MSE-2 sites in the salt marsh areas of the Nalón river estuary 
Table 2 Mean rates of sedimentation $\left(\mathrm{S}, \mathrm{cm}_{\text {year }}{ }^{-1}\right)$ and mass accumulation $\left(\mathrm{A}, \mathrm{g} \mathrm{cm}^{-2}\right.$ year $\left.{ }^{-1}\right)$, calculated on the basis of ${ }^{210} \mathrm{~Pb}$ and ${ }^{137} \mathrm{Cs}$ for each core. CF refers to results based on the constant flow model

\begin{tabular}{|c|c|c|c|c|c|}
\hline & $\begin{array}{l}\mathrm{S}_{210} \\
\left(\mathrm{~cm}_{\text {year }}{ }^{-1}\right)\end{array}$ & $\begin{array}{l}\mathrm{A}_{210} \\
\left(\mathrm{~g} \mathrm{~cm}^{-2} \text { year }^{-1}\right)\end{array}$ & $\begin{array}{l}{ }^{210} \mathrm{~Pb} \\
\text { method }\end{array}$ & $\begin{array}{l}\mathrm{S}_{137} \\
\left(\mathrm{~cm}_{\text {year }}^{-1}\right)\end{array}$ & ${ }^{137} \mathrm{Cs}$ method \\
\hline MSE-1 & 0.29 & 0.17 & $\mathrm{CF}$ & 0.28 & Atmospheric nuclear test peak \\
\hline MSE-2 & 0.37 & 0.22 & $\mathrm{CF}$ & 0.35 & Atmospheric nuclear test peak \\
\hline
\end{tabular}

In addition, if grain-size profiles are compared, the MSE-2 sediment core shows a greater percentage of sands than the eastern salt marsh core, thus confirming that the western salt marsh core was taken from a more active depositional zone where the loss of sedimentary load is more effective; contrasts may also be due to salt wedge penetration during flood tides.

\section{Chronology of the vertical profiles of As-Hg-Sb}

Down-core distributions of $\mathrm{Hg}$, As, and $\mathrm{Sb}$ (Fig. 3) are similar for each salt marsh, suggesting a highly significant relationship among these elements. In fact, As is well correlated with $\mathrm{Hg}\left(r^{2}=0.858 ; p<0.001\right)$ and $\mathrm{Sb}\left(r^{2}=0.816 ; p<0.001\right)$, as are $\mathrm{Hg}$ and $\mathrm{Sb}\left(r^{2}=0.760 ; p<0.001\right)$, supporting the hypothesis that the source for the three elements is the same and is related to the $\mathrm{Hg}$ mines (Ordoñez et al. 2013). The profiles of the three trace elements in the two cores show a distinctive trend which clearly reflects a recent contamination process of the estuarine zone that is well recorded in the salt marsh sediments. The concentrations of the three elements increase from the surface to a depth of about $15 \mathrm{~cm}$, where a concentration peak of $87.5,3.7$, and $5.7 \mathrm{\mu g} \mathrm{g}^{-1}$ is reached for $\mathrm{As}, \mathrm{Hg}$, and $\mathrm{Sb}$, respectively, in core MSE-1; the peak concentrations in core MSE-2 are 85.0, 3.2, and $4.9 \mu \mathrm{g} \mathrm{g}^{-1}$, respectively. Below this depth, the abundance of As and Sb decreases, nearly exponentially, down to a depth of about $30 \mathrm{~cm}$, where the element concentrations reach values which remain almost constant down to the core bottom in both salt marshes. In contrast, $\mathrm{Hg}$ contents decrease constantly from the peak down-core to the bottom in the cores from both sites.

The chronology provided by ${ }^{210} \mathrm{~Pb}$ and ${ }^{137} \mathrm{Cs}$ activities (Fig. 4) indicates increasing $\mathrm{As}, \mathrm{Hg}$, and $\mathrm{Sb}$ concentration from the late nineteenth century (1885). The element concentration peaks can be dated back to a time interval between the 1960 s and 1970s. Subsequent to that date, a decrease in the concentrations of the three elements to the present time is observed. The profiles of As-Hg-Sb concentrations in these cores reflect the history of mining in the region.

\section{Pre-mining levels and incidence of $\mathbf{H g}$ mining}

According to the geochronology of the salt marsh sediment cores, the basal part of the cores, below $50 \mathrm{~cm}$, corresponds to the pre-mining period, before the beginning of the nineteenth century. Concentration profiles of As-Hg-Sb observed in these pre-mining segments in both cores present similar trends: average pre-mining concentrations are $31.8 \mu \mathrm{g} \mathrm{g}^{-1}$ for As, $0.33 \mu \mathrm{g} \mathrm{g}^{-1}$ for $\mathrm{Hg}$, and $2.7 \mu \mathrm{g} \mathrm{g}^{-1}$ for $\mathrm{Sb}$. In general, when comparing these average concentrations with those reported for European sediments $\left(6.0,0.04\right.$, and $0.6 \mu \mathrm{g} \mathrm{g}^{-1}$, respectively in accordance with Salminen et al. 2005) and Spanish sediments $\left(12.2,0.02\right.$, and $1.1 \mathrm{\mu g} \mathrm{g}^{-1}$, respectively, following IGME 2012), the detected values in the salt marsh cores are higher than the reference values. In addition, since $\mathrm{Hg}$ or other trace elements such as As may derive from aerosols released by various anthropogenic activities (Shotyk 2002; Moreno et al. 2005), the atmospheric input must be taken into account. In the Roñanzas Peat Bog close to Ribadesella (Asturias), Gallego et al. (2013) evaluated the aerial deposition in the north of Spain based on elements profiles of peat bog soil. The Hg contribution in the modern period (1750-2000) by aerial deposition reached a maximum of $0.20 \mu \mathrm{g} \mathrm{g}^{-1}$ which is lower than the $\mathrm{Hg}$ pre-mining concentrations estimated in this study. As a consequence, this evidence indicates that the aerial deposition of $\mathrm{Hg}$ and the other elements in the salt marshes is negligible when compared with the natural background due to the presence of mineralised deposits that act as a geogenic source of these elements.

Industrial-scale (Fig. 5) development of mercury mining in the Nalón river basin, from 1850 to 1969 , produced 8600 t of mercury (250,000 flasks) (Luque and Gutierrez-Claverol 2006). The profiles of As-Hg-Sb concentrations along the cores seem to follow the historical $\mathrm{Hg}$ mining activity in the river basin. The detected increases and decreases in concentration of the three elements coincide with the dates of the mining periods. In particular, the maximum detected concentrations dated to the end of the 1960s, during the height of mining production. The cessation of extraction activity in 1969 is indicated in the cores by a decrease in concentration of the three elements from their maximum values up to the core top. When the actual surface sediment concentrations are compared to those from the pre-mining period, the difference suggests that large amounts of mine waste are still present in the drainage basin of the Nalón River.

Hydrological factors controlling the transport of elements from the river basin to the estuary are significant and should also be taken into account in elucidating the geochronological sequence of the estuarine sediments. The apparent null delay 
Fig. $5 \mathrm{Hg}$ production in Asturias since 1850 till the present time (data extracted from the annual mining statistics of Spanish bulletin 1850-2017)

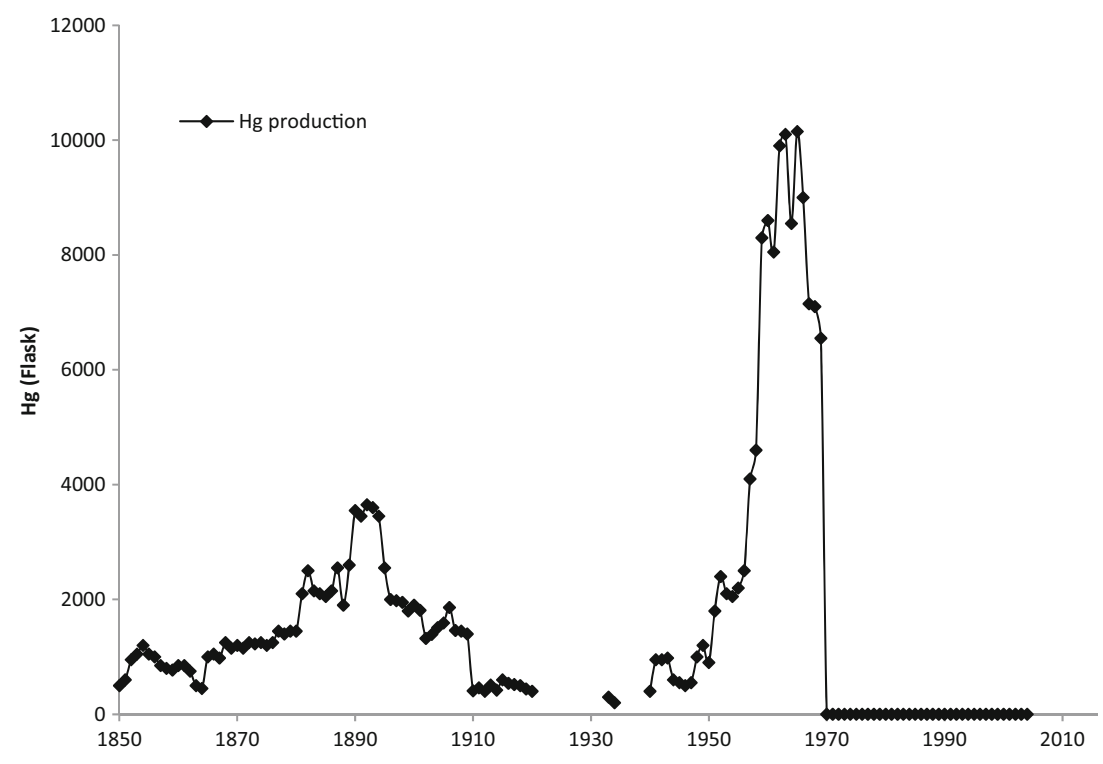

between the time of the highest mining production and the peak $\mathrm{Hg}$ concentration in the cores suggests two important realities. First, rivers carried an important anthropogenic metal load downstream from the mines during the $\mathrm{Hg}$ mining period, as revealed by the vertical metal profiles in the sediment cores. Second, part of this anthropogenic load remains in different compartments of the river basin and is being gradually released into the fluvial environment, as indicated by the absence of a drastic decrease in concentrations in the vertical profiles following the cessation of mining.

\section{As-Hg-Sb stored in the salt marshes}

The absence of relevant post-depositional migrations or remobilisation of $\mathrm{As}-\mathrm{Hg}-\mathrm{Sb}$ from bottom sediments after deposition allows a geochronological reconstruction of the element supply in recent sediments. In particular, the anthropogenic component can be described by considering the productivity of the $\mathrm{Hg}$ mines in the basin. Based on this reconstruction, a first cumulative element inventory may be estimated. The cumulative element inventory quantifies the total amount of the element loaded to the salt marsh sediments over time. If the natural input of an element is removed by subtracting the baseline concentration from the total concentration, the inventory represents only the anthropogenic load. In this case, the premining estimates from the lower part of the cores have been used to calculate the salt marsh inventory of anthropogenic As$\mathrm{Hg}-\mathrm{Sb}$. To calculate the inventory of each element, the accumulation rate $\left(\right.$ Metal $\left._{\mathrm{AR}}\right)$ in sediments is first calculated from the following eqs. (1), (2), after Covelli et al. (2006):

$$
\begin{aligned}
& \operatorname{Metal}_{A R}\left(\mu g m^{-2} y r^{-1}\right)=\omega x(\text { Metal content }) s \times 10^{4} \\
& \text { with } \omega=(1-\varphi) x v x \rho
\end{aligned}
$$

where $\omega$ is the mass sedimentation rate $\left(\mathrm{g} \mathrm{cm}^{-2} \mathrm{year}^{-1}\right)$, (Metal content)s is the element concentration in sediment $\left(\mu \mathrm{g} \mathrm{g}^{-1}\right), \varphi$ is porosity, $\nu$ is sedimentation rate $\left(\mathrm{cm}\right.$ year $\left.{ }^{-1}\right)$, and $\rho$ is sediment density $\left(\mathrm{g} \mathrm{cm}^{-3}\right)$. As the geometry of the samples is similar (radius of liner, $4 \mathrm{~cm}$; thickness of sample specimen, $2 \mathrm{~cm}$ ), the porosity and density of each sample were estimated based on the geometry and the difference between wet and dry weights. The temporal variability of excess $\mathrm{As}, \mathrm{Hg}$, and $\mathrm{Sb}$ due to anthropogenic activity was estimated from the difference between the total and pre-mining levels as described in section 3.3. By applying the average sedimentation rates estimated on the basis of ${ }^{210} \mathrm{~Pb}$ activity in cores MSE-1 and MSE-2, and taking into account the vertical variability of porosity and density (Fig. 6), accumulation rates or fluxes of the three elements along the core profiles were determined and are reported in Fig. 7. From the vertical profiles, dry density slightly increases from the bottom to the core top in spite of the greater quantity of organic matter. This fact is attributed to the contributions from mining activities which have increased the amount of heavy minerals that offset the major presence of organic matter.

Conversion of the vertical profiles (sediment depth) to estimated calendar age (Fig. 6) revealed that fluxes of As, $\mathrm{Hg}$, and $\mathrm{Sb}$ in the salt marsh sediments due to anthropogenic activity have significantly increased. According to the vertical profiles, the key date seems to be around 1920, when the onset of the increase in anthropogenic $\mathrm{As}, \mathrm{Hg}$, and $\mathrm{Sb}$ in both salt marshes is apparent. Although $\mathrm{Hg}$ mining activity began in the middle of the nineteenth century, the results obtained from our cores show a clear delay in anthropogenic $\mathrm{As}, \mathrm{Hg}$, and $\mathrm{Sb}$ enrichment in the salt marsh sediments. The contribution of early mining activity was probably not sufficient to be recorded in the sedimentary sequence, or the delay may correspond to the time interval necessary for the contaminated sediments to reach the estuarine environment. 
Fig. 6 Vertical profiles of sedimentation rate, dry density and porosity in the salt marsh cores
Sedimentation rate $\left(\mathrm{cm} \mathrm{y}^{-1}\right)$

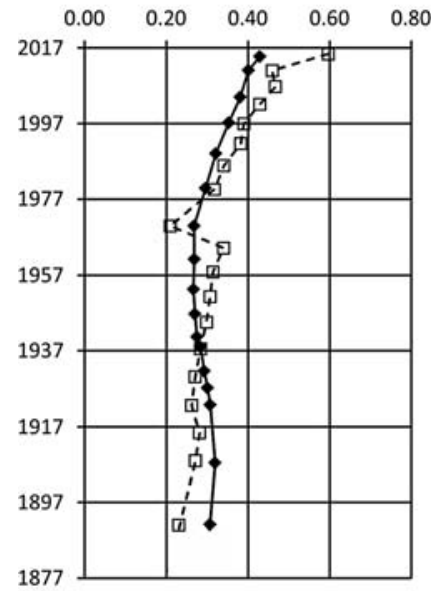

\section{Density} $\left(\mathrm{g} \mathrm{cm}^{-3}\right)$
Porosity

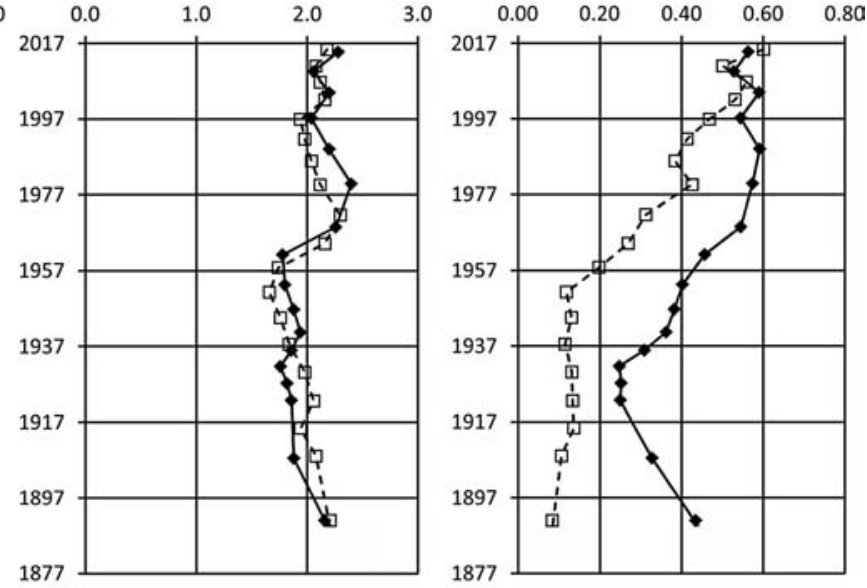

An assessment of the total concentration of each element in the sedimentary columns from the beginning of the mining period was attempted through the estimation of the inventory [3] for each element in the sediment cores in accordance with Covelli et al. (2006):

$\operatorname{Met}_{\text {inv }}\left(m g m^{-2}\right)=\sum\left[\left(\operatorname{Met}^{*}\right)_{s}(1-\varphi) x \rho x d\right] \times 10$

where $\left(\mathrm{Met}^{*}\right)_{s}$ is the concentration in the sediment corrected for the pre-mining baseline value and $d$ in centimeters is the thickness of sediment between two consecutive analysed core subsamples. The cumulative Met inventory is the total mass of

Fig. 7 Estimated accumulation rates or fluxes of anthropogenic $\mathrm{As}-\mathrm{Hg}-\mathrm{Sb}$ in salt marsh core sediments

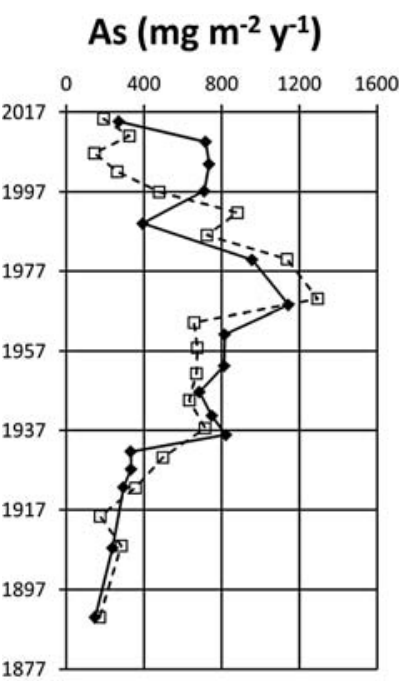

the selected element due to mining input deposited on a $1-\mathrm{m}^{2}$ surface area.

The results (Table 3) show only slight differences between the two sites, especially for the amount per unit area of As, which is higher in the MSE-1 core than in the MSE-2 core. Based on these inventories, a rough estimation of the total amount of each element buried in the salt marsh sediments of the Nalón river estuary can be attempted. Although a large number of core profiles would be necessary to better define the spatial variability of the elements in the sedimentary sequence, we may assume that each core is representative of each salt marsh in terms of sedimentary column and temporal

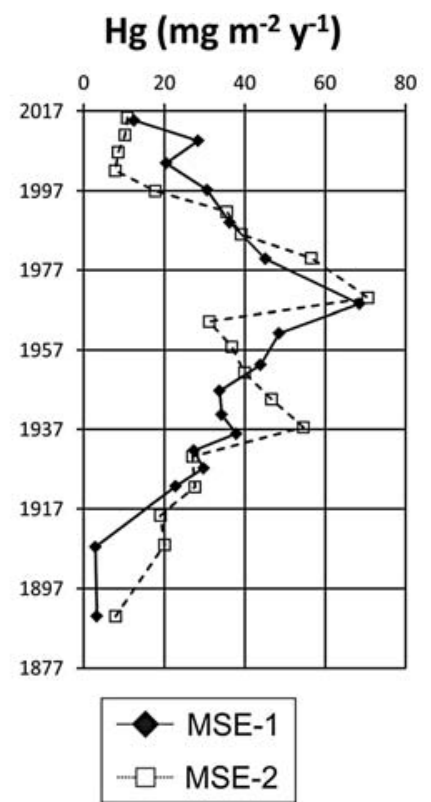

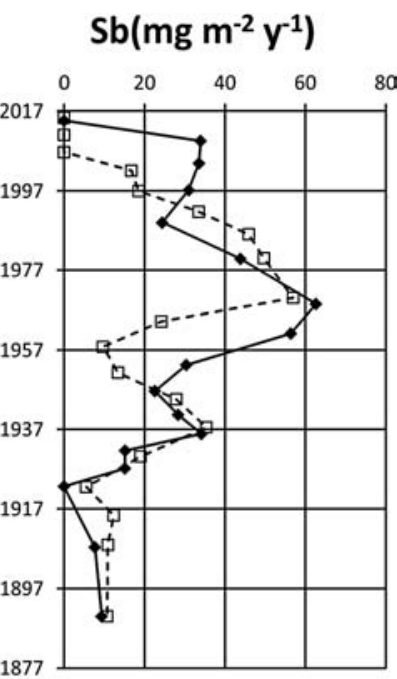


Table 3 Inventory of As- $\mathrm{Hg}-\mathrm{Sb}$ in cores due to mining contributions in the period $1890-2017$

\begin{tabular}{|c|c|c|c|c|c|}
\hline & \multirow[t]{2}{*}{ As baseline $\left(\mu \mathrm{g} \mathrm{g}^{-1}\right)$} & \multicolumn{3}{|c|}{$\begin{array}{l}\text { As total accumulation rate } \\
\text { post-1890 }\left(\mathrm{mg} \mathrm{m}^{-2} \text { year }^{-1}\right)\end{array}$} & \multirow[t]{2}{*}{$\begin{array}{l}\text { As inventory } \\
(1890-2017)\left(\mathrm{mg} \mathrm{m}^{-2}\right)\end{array}$} \\
\hline & & Surface & Peak & Average & \\
\hline MSE-1 & 31.8 & 269.9 & 1144.3 & 564.7 & $71,713.4$ \\
\hline \multirow[t]{2}{*}{ MSE-2 } & 31.8 & 192.0 & 1294.8 & 541.1 & $68,719.0$ \\
\hline & Hg baseline $\left(\mu \mathrm{g} \mathrm{g}^{-1}\right)$ & \multicolumn{3}{|c|}{$\begin{array}{l}\mathrm{Hg} \text { total accumulation rate } \\
\text { post-1890 }\left(\mathrm{mg} \mathrm{m}^{-2} \text { year }^{-1}\right)\end{array}$} & $\begin{array}{l}\mathrm{Hg} \text { inventory } \\
\quad(1890-2017)\left(\mathrm{mg} \mathrm{m}^{-2}\right)\end{array}$ \\
\hline MSE-1 & 0.33 & 12.5 & 68.5 & 29.2 & 3718.0 \\
\hline \multirow[t]{2}{*}{ MSE-2 } & 0.33 & 10.8 & 70.8 & 29.9 & 3800.1 \\
\hline & Sb baseline $\left(\mu \mathrm{g} \mathrm{g}^{-1}\right)$ & \multicolumn{3}{|c|}{$\begin{array}{l}\text { Sb total accumulation rate } \\
\text { post- } 1890\left(\mathrm{mg} \mathrm{m}^{-2} \text { year }^{-1}\right)\end{array}$} & $\begin{array}{l}\text { Sb inventory } \\
\quad(1890-2017)\left(\mathrm{mg} \mathrm{m}^{-2}\right)\end{array}$ \\
\hline MSE-1 & 3.7 & 0 & 62.6 & 25.0 & 3166.9 \\
\hline MSE-2 & 3.7 & 0 & 35.4 & 23.2 & 2611.3 \\
\hline
\end{tabular}

variability of trace element concentration. Based on these assumptions and considering the inventory of each salt marsh (Fig. 1), a rough estimate, approximate by default, of the amount of As, $\mathrm{Hg}$, and $\mathrm{Sb}$ 'trapped' in the salt marsh sediments of the Nalón estuary is about 18.7, 1.0, and 0.7 t, respectively, with the majority buried in the western salt marsh (around $72 \%$ ). Taking into account the As input of $12 \mathrm{t} \mathrm{year}^{-1}$ to the river drainage basin after the closure of the mining activity (Ordoñez et al. 2013) and the calculated As trapped in the salt marsh sediments in the most recent sedimentary sequence, a gross estimation of the retention in these areas shows that the majority (99\%) of As and probably of $\mathrm{Hg}$ and $\mathrm{Sb}$ have been discharged into the Cantabrian sea or have been stored in the estuary channel. The marsh areas thus retain less than $1 \%$ of the total. Although several simplifying approximations were used in this estimation, the results are approximately one order of magnitude higher than similar assessments reported in the literature for salt marshes (Bricker 1996; Connor et al. 2001), suggesting that our estimate of retention is fairly realistic due to the major inputs produced during river flood events.

\section{Environmental implications}

The average pre-mining concentrations in the sediments (31.8 $\mu \mathrm{g} \mathrm{g}^{-1}$ for As, $0.33 \mu \mathrm{g} \mathrm{g}^{-1}$ for $\mathrm{Hg}$, and $2.7 \mu \mathrm{g} \mathrm{g}^{-1}$ for $\mathrm{Sb}$ ) are systematically above the reference values used to
Fig. 8 Calculated Igeo for As$\mathrm{Hg}-\mathrm{Sb}$ in salt marsh core sediments
Igeo As

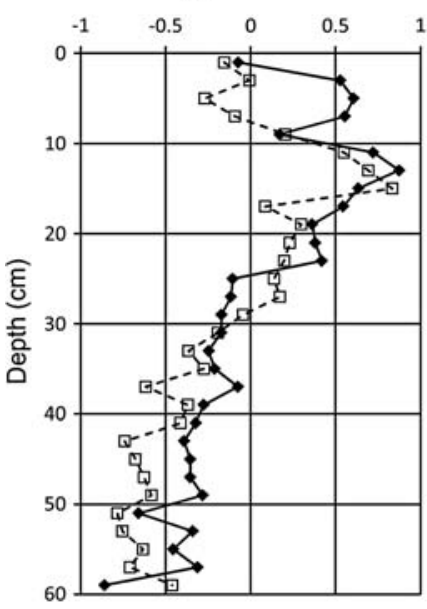

MSE-1 MSE-2
Igeo $\mathrm{Hg}$
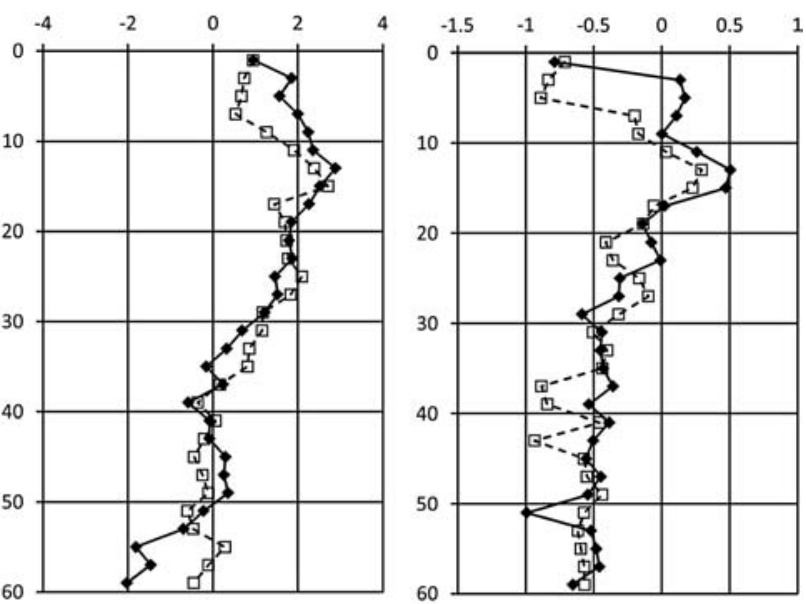

Igeo $<0$ - Uncontaminated

$0<$ Igeo $<1$ - Uncontaminated to moderatelly contaminated $1<$ Igeo $<2$ - Moderately contaminated $2<$ Igeo $<3$ - Moderately to heavily contaminated $3<$ Ige $<4$ - Heavily contaminated

$4<$ Igeo $<5$ - Heavily to extremely contaminated Igeo>5 - Extremely contaminated 
estimate the potential risk for biota, such as the US National Oceanic and Atmospheric Administration (Buchman 2008) or the Canadian Council of Ministers of the Environment (CCME 2001). Therefore, taking into consideration the particular geological context of the study area, a comparison with these values is not realistic and would lead to a misleading interpretation. However, an approximate assessment of the "potential risk" for the biota due to trace metal sediment contamination may be done through the geoaccumulation index (Igeo) (Müller 1969). This index was selected due to its simplicity of use and the excellent results obtained to evaluate the sediment quality of other potentially contaminated ecosystems (e.g. Hasan et al. 2013; Garcia-Ordiales et al. 2015). The Igeo is expressed as follows:

$I_{\text {geo }}=\log _{2} \frac{\mathrm{Cn}}{1.5 B_{n}}$

where $\mathrm{Cn}$ is the measured concentration of the metal $(n)$ in the sediment, $\mathrm{Bn}$ is the background value for the metal $(n)$, and the factor 1.5 is introduced to include possible differences in the background values due to lithological variations.

The results (Fig. 8) are interpreted in accordance with the six contamination levels proposed by Müller (1981). Arsenic and $\mathrm{Sb}$ Igeo values show that sediments can be considered as showing a low level of contamination in spite of the high concentrations detected, thus suggesting a low potential risk for both elements. Conversely, this not true for $\mathrm{Hg}$, since, for most of the core levels in the upper part of the vertical profiles, the metal enrichments show significant contamination and a potential risk for the biota. In fact, the upper parts of the sedimentary sequence in both cores are coincident with the rhizosphere for plants. These are able to uptake trace metals through their root system, may immobilise or possibly translocate small amounts of these elements into the aerial parts (Petranich et al. 2017). In addition, since salt marshes are often threatened by erosive processes due to human activities which are coupled with sea-level rise and the negative sediment budget (Fontolan et al. 2012), a certain amount of As, $\mathrm{Hg}$, and $\mathrm{Sb}$ "entrapped" in these salt marshes could be remobilised and dispersed into the estuarine environment thus producing potential adverse effects to the aquatic biota.

\section{Conclusions}

In the coastal marine area of the Nalón river estuary, salt marsh sediments are undoubtedly able to record the contamination suffered by the aquatic environment as consequence of historical $\mathrm{Hg}$ mining. The basal sections of both cores consist of sediments which do not show contributions from $\mathrm{Hg}$ mines, establishing reference values for future studies in the area and highlighting, on the one hand, the difference between the impacted sediments located in the middle sections and, on the other hand, how after cessation of mining, natural attenuation has gradually reduced the contaminant inputs to the estuary, as shown by the top sections of the cores. The profiles of both cores also provide information on the development of these morphological structures in terms of sediment accumulation rates. The assessment of the current status and the history of contamination may be important for future conservation and management plans for the salt marshes including, for instance, the periodic deposits of dredged sediments from the channel. Also, as these deposits may suffer erosive processes or translocations between environmental compartments, they represent potential sources of contaminants not only within the estuary environment but also in the nearby Cantabrian sea coastal environments through tidal flux exchange. Protection and study of these salt marshes should be taken into consideration from this point of view as well as based on their importance as ecological niches for salt marshdependent animals and halophytic vegetable species.

Funding This study was co-supported by the Spanish Ministry of Economy, Industry and Competitiveness through the Research Project METRAMER [grant number MINECO-13-CGL2013-44980-R] and the Asturias Ministry of Education and Science [grant number FC-15GRUPIN14-067]. The authors are sincerely grateful to two anonymous reviewers for their help in improving an early version of the manuscript. Karry Close is warmly acknowledged for proofreading the final version of the manuscript.

\section{References}

Allen JRL (1989) Evolution of salt-marsh cliffs in muddy and sandy systems: a qualitative comparison of British West-Coast estuaries. Earth Surf Process Landf 14(1):85-92

Allen JRL, Rae JE (1988) Vertical salt-marsh accretion since the Roman Period in the Severn Estuary, southwest Britain. Mar Geol 83(1-4): 225-235

Andersen TJ (2017) Some practical considerations regarding the application of $210 \mathrm{~Pb}$ and $137 \mathrm{Cs}$ dating to estuarine sediments. In: Applications of paleoenvironmental techniques in estuarine studies. Springer Netherlands, Dordrecht, pp 121-140

Appleby PG, Oldfield F (1983) The assessment of $210 \mathrm{~Pb}$ data from sites with varying sediment accumulation rates. In: Paleolimnology. Springer Netherlands, Dordrecht, pp 29-35

Audry S, Blanc G, Schäfer J (2005) The impact of sulphide oxidation on dissolved metal $(\mathrm{Cd}, \mathrm{Zn}, \mathrm{Cu}, \mathrm{Cr}, \mathrm{Co}, \mathrm{Ni}, \mathrm{U})$ inputs into the LotGaronne fluvial system (France). Appl Geochem 20(5):919-931

Birch GF (2017) Determination of sediment metal background concentrations and enrichment in marine environments - a critical review. Sci Total Environ 580:813-831

Buchman MF (2008) NOAA Screening Quick Reference Tables. Office of Response and Restoration Division, National Oceanic and Atmospheric Administration, Seattle WA, p. 2

Bricker SB (1996) Retention of sediment and metals by Narragansett Bay subtidal and marsh environments: an update. Sci Total Environ 179: $27-46$

CCME (2001) Canadian sediment quality guidelines for the protection of aquatic life. Canadian Council of Ministers of the Environment, Winnipeg 
Cearreta A, Edeso JM, Ugarte FM (1992) Cambios del nivel del mar durante el Cuaternario reciente en el Golfo de Bizkaia. In: The late Quaternary in the Western Pyrenean Region. UPV, Bilbao, pp 57-94

Cearreta A, Leorri ES (2009) El registro geológico de la transformación ambiental de la ría de Bilbao durante el Holoceno y el Antropoceno. Sociedad de ciencias aranzadi zientzi elkartea, San Sebastian

Chen CW, Kao CM, Chen CF, Dong CD (2007) Distribution and accumulation of heavy metals in the sediments of Kaohsiung Harbor, Taiwan. Chemosphere 66(8):1431-1440

Conaway CH, Watson EB, Flanders JR, Flegal AR (2004) Mercury deposition in a tidal marsh of south San Francisco Bay downstream of the historic New Almaden mining district, California. Mar Chem 90(1):175-184

Connor RF, Chmura GL, Beecher CB (2001) Carbon accumulation in Bay of Fundy salt marshes: implications for restoration of reclaimed marshes. Glob Biogeochem Cycles 15(4):943-954

Covelli S, Langone L, Acquavita A, Piani R, Emili A (2012) Historical flux of mercury associated with mining and industrial sources in the Marano and Grado lagoon (northern Adriatic Sea). Estuar Coast Shelf Sci 13:7-19

Covelli S, Fontolan G, Faganeli J, Ogrinc N (2006) Anthropogenic markers in the Holocene stratigraphic sequence of the Gulf of Trieste (northern Adriatic Sea). Mar Geol 230(1):29-51

Cuvilliez A, Lafite R, Deloffre J, Lemoine M, Langlois E, Sakho I (2015) River flow control on intertidal mudflat sedimentation in the mouth of a macrotidal estuary. Geomorphology 239:174-181

De Cort M, Dubois G, Fridman SD, Germenchuk MG, Izrael YA, Janssens A, Jones AR, Kelly GN, Kvasnikova EV, Matveenko II, Nazarov IM, Pokumeiko YM, Sitak VA, Stukin ED, Tabachny LY, Tsaturov YS, Avdyushin SI (1998) Atlas of Caesium Deposition on Europe after the Chernobyl Accident. Office for Official Publications of the European Communities, Luxembourg

Duarte B, Vaz N, Valentim JM, Dias JM, Silva H, Marques JC, Sleimi N, Caçador I (2017) Revisiting the outwelling hypothesis: modelling salt marsh detrital metal exports under extreme climatic events. Mar Chem 191:24-33

Flor G, Ceñal RC, González MS, Ortega MI (1998) Aspectos morfológicos, dinámicos y sedimentológicos del estuario del Nalón (Asturias, noroeste de España). Trab Geol 20(20):3-39

Flor-Blanco G, Pando L, Morales JA, Flor G (2015) Evolution of beachdune fields systems following the construction of jetties in estuarine mouths (Cantabrian coast, NW Spain). Environ Earth Sci 73(3): $1317-1330$

Gallego JLR, Ortiz JE, Sierra C, Torres T, Llamas JF (2013) Multivariate study of trace element distribution in the geological record of Roñanzas Peat Bog (Asturias, N. Spain). Paleoenvironmental evolution and human activities over the last 8000 calyr BP. Sci Total Environ 454:16-29

García-Ordiales E, Loredo J, Esbrí JM, Lominchar MA, Millán R, Higueras P (2014) Stream bottom sediments as a mean to assess metal contamination in the historic mining district of Almadén (Spain). Int J Min Reclam Environ 28(6):357-376

Garcia-Ordiales E, Loredo J, Cienfuego P, Covelli S, Flor-Blanco G, Fontolan G, Roqueñí N, Ordoñez A, Flor G (2015) Metales pesados y metaloides en sedimentos de las Marismas del Estuario del río Nalón (Norte de España). Comunicaçõe Geológicas 102:69-72

Fontolan G, Pillon S, Bezzi A, Villalta R, Lipizer M, Triches A, D'Aietti A (2012) Human impact and the historical transformation of saltmarshes in the Marano and Grado Lagoon, northern Adriatic Sea. Estuar Coast Shelf Sci 113:41-56

Hammarstrom JM, Seal RR, Meier AL, Kornfeld JM (2005) Secondary sulfate minerals associated with acid drainage in the eastern US: recycling of metals and acidity in surficial environments. Chem Geol 215(1):407-431

Hasan AB, Kabir S, Reza AS, Zaman MN, Ahsan A, Rashid M (2013) Enrichment factor and geo-accumulation index of trace metals in sediments of the ship breaking area of Sitakund Upazilla (Bhatiary-Kumira), Chittagong, Bangladesh. J Geochem Explor 125:130-137

Heiri O, Lotter AF, Lemcke G (2001) Loss on ignition as a method for estimating organic and carbonate content in sediments: reproducibility and comparability of results. J Paleolimnol 25(1):101-110

Idaszkin YL, del Pilar Alvarez M, Carol E (2017) Geochemical processes controlling the distribution and concentration of metals in soils from a Patagonian (Argentina) salt marsh affected by mining residues. Sci Total Environ 596:230-235

IGME (2012) Geochemical atlas of Spain (Atlas Geoquímico de España). Instituto Geológico y Minero de España, Madrid In Spanish

Julivert, M., Fontbote, J. M., Ribeiro, A., Conde, L. (1972). Mapa tectónica de la Península Ibérica y Baleares 1: 1'000 000. Inst. Geol. Min. Esp. Madrid

Larsonneur C (1975) Tidal deposits, Mont Saint-Michel Bay, France. In: Tidal deposits. Springer Berlin, Heidelberg, pp 21-30

Luque C (1985) Las mineralizaciones de mercurio de la Cordillera Cantábrica. PhD Thesis, University of Oviedo, Spain In spanish

Luque C, Gutiérrez Claverol M (2006) La minería del mercurio en Asturias. Rasgos históricos. Ed. Eujoa, Mieres, España, In Spanish, p 560

Mahu E, Nyarko E, Hulme S, Swarzenski P, Asiedu DK, Coale KH (2016) Geochronology and historical deposition of trace metals in three tropical estuaries in the Gulf of Guinea. Estuar Coast Shelf Sci 177:31-40

Mantecón VR, Uceda AC (1992) Análisis histórico de la evolución superficial de los estuarios del País Vasco. Lurralde: Investigación y espacio 15:199-227

Moore DM, Reynolds RC (1989) X-ray diffraction and the identification and analysis of clay minerals, vol 378 . Oxford university press, Oxford, $\mathrm{p} 155$

Moreno T, Higueras P, Jones T, McDonald I, Gibbons W (2005) Size fractionation in mercury-bearing airborne particles ( $\mathrm{HgPM} \mathrm{10)}$ at Almadén, Spain: implications for inhalation hazards around old mines. Atmos Environ 39(34):6409-6419

Müller G (1969) Index of geoaccumulation in sediments of the Rhine River. GeoJournal 2:108-118

Müller G (1981) Die Schwermetallbelastung der Sedimenten des Neckars und Seiner Nebenflu"sse. Chemiker-Zeitung 6:157-164

Ordóñez A, Álvarez R, Loredo J (2013) Asturian mercury mining district (Spain) and the environment: a review. Environ Sci Pollut Res 20(11):7490-7508

Pasternack GB, Brown KJ (2006) Natural and anthropogenic geochemical signatures of floodplain and deltaic sedimentary strata, Sacramento-San Joaquin Delta, California, USA. Environ Pollut 141(2):295-309

Petranich E, Acquavita A, Covelli S, Emili A (2017) Potential bioaccumulation of trace metals in halophytes from salt marshes of a northern Adriatic coastal lagoon. J Soils Sediments 17:1986-1998

Ritchie JC, McHenry JR (1990) Application of radioactive fallout cesium-137 for measuring soil erosion and sediment accumulation rates and patterns: a review. J Environ Qual 19(2):215-233

Roner M, D'Alpaos A, Ghinassi M, Marani M, Silvestri S, Franceschinis E, Realdon N (2016) Spatial variation of salt-marsh organic and inorganic deposition and organic carbon accumulation: inferences from the Venice lagoon, Italy. Adv Water Resour 93:276-287

Sahu BK (1964) Depositional mechanisms from the size analysis of clastic sediments. J Sediment Res 34(1):73-83

Salminen R, Batista MJ, Bidovec M, Demetriades A, De Vivo B, De Vos W, Duris M, Gilucis A, Gregorauskiene V, Halamic J, Heitzmann P, Lima A, Jordan G, Klaver G, Klein P, Lis J, Locutura J, Marsina K, Mazreku A, O'Connor PJ, Olsson S, Ottesen RT, Petersell V, Plant JA, Reeder S, Salpeteur I, Sandström H, Siewers U, Steenfeldt A, Tarvainen T (eds) (2005) FOREGS geochemical atlas of Europe, 
part 1 - background information, methodology and maps. geological survey of Finland, Espoo

Sanchez-Cabeza JA, Ruiz-Fernández AC, Ontiveros-Cuadras JF, Bernal LHP, Olid C (2014) Monte Carlo uncertainty calculation of $210 \mathrm{~Pb}$ chronologies and accumulation rates of sediments and peat bogs. Quat Geochronol 23:80-93
Shotyk W (2002) The chronology of anthropogenic, atmospheric Pb deposition recorded by peat cores in three minerogenic peat deposits from Switzerland. Sci Total Environ 292(1):19-31

Verney R, Lafite R, Brun-Cottan J-P, Le Hir P (2011) Behaviour of a floc population during a tidal cycle: laboratory experiments and numerical modeling. Cont Shelf Res 31(10):S64-S83 